\title{
PESTICIDES: CLASSIFICATIONS, EXPOSURE AND RISIKS TO HUMAN HEALTH
}

\section{Weis GCC}

Graduate Program of Food Science and Technology, Federal University of Santa Maria; Laboratory of Persistent Polluent Analyses, Health Sciences Center, Federal University of Santa Maria; grazielle.castagna@gmail.com; http://orcid.org/0000-0003-0906-1224

Alves AO

Graduate Program of Pharmacology, Federal University of Santa Maria, Santa Maria, RS, Brazil; audrei.alves77@gmail.com; https://orcid.org/0000-0002-5563-6415

\section{Assmann CE}

Graduate Program of Biological Sciences (Toxicological Biochemistry), Federal University of Santa Maria; charles.ufsm@gmail.com; https://orcid.org/0000-0002-3524-3446

\section{Bonadiman BSR}

Graduate Program of Biochemistry, Federal University of Santa Catarina; beadasilvarosa@ gmail.com; https://orcid.org/0000-0002-1968-0320

\section{Costabeber IH}

Laboratory of Persistent Polluent Analyses, Health Sciences Center, Federal University of Santa Maria; 1000 Roraima Av. Building \#19, Suite 3201/3204, 97105-900, Santa Maria, Rio Grande do Sul, Brazil; ijonicostabeber@gmail.com; https://orcid.org/0000-00018169-5112

Abstract: Pesticides are used in the control and prevention of pests, improving the productivity and the quality of agricultural production. The adoption of the Brazilian agricultural model, which uses pesticides on a large scale and indiscriminately, has been worrying public authorities about their impacts on human health and environmental sustainability. Thus, studies that contribute to a better understanding of agrochemicals and their effects on ecosystems and human health are timely. The aim was to investigate the 
history of the production and use of pesticides, their classifications, sources of exposure and their risks to human health. The research was carried out through literature review in databases to verify scientific information about the history of pesticides, structural and toxicological classifications, sources of exposure and their risks to human health. The use of pesticides dates back many years. During the nineteenth century until the midtwentieth century, some chemicals nowadays used was pesticides were used for public health or for war purposes. About the classification of pesticides, due to the different biological targets, the agrochemicals market is segmented into different action targets (herbicides, fungicides and insecticides). Pesticides can be classified as contact, ingestion or systemic according to the mode of action. As for the chemical structure, the main classes of pesticides are organochlorines, organophosphates, pyrethroids and carbamates. The toxicity of pesticides ranges from low toxic to extremely toxic. Exposure to pesticides can occur directly through occupational exposure, or indirectly, through environmental exposure and food. The impacts on human health are divided into acute and chronic form. The prolonged human exposure to pesticides may result in neurological, reproductive, teratogenic and immunological disorders. The results presented in this literature review contribute to a better understanding of agrochemicals and their effects on human health. Keywords: Agrochemicals. Class. Contamination. Health disorders.

\section{INTRODUCTION}

Pesticides are used in the control and prevention of pests during cultivation and after harvesting, improving the productivity and the quality of agricultural production., ${ }^{1,2}$

In Brazil, the pesticides are extensively used, making the country the largest consumer of these substances in the world, accounting for $19 \%$ of world use. . $^{3,4}$

In the 2015 harvest, 899 million liters of agrochemicals were sprayed in the national crops, representing an average of 12.6 liters per hectare and average environmental, occupational and food exposure of 4.4 liters of pesticides per inhabitant per year. ${ }^{5}$

These substances used have several denominations, among them are pesticides, biocides, poisons and agrochemicals. ${ }^{6}$ Several are the active principles used as pesticides. These present different spectra of action, chemical structure and toxicological classifications, which will interfere in its mode of action and in the risks that exposure to these substances can cause. ${ }^{7}$ 
Every year in Brazil, according to the Brazilian health organization, 400,000 new cases of poisoning by pesticides are registered with a rate of $1 \%$ of deaths. ${ }^{4}$ However, it is believed that there is underreporting of the intoxications occurrence, considering that Brazil does not have an adequate system of records, these being the companies acting in the cases and also not differentiated as acute and chronic intoxications. ${ }^{4}$ In addition, the prolonged human exposure to agrochemicals can trigger neurological, reproductive, teratogenic and immunological disturbances. ${ }^{8-10}$

The adoption of the Brazilian agricultural model, which uses pesticides on a large scale and indiscriminately, has been worrying public authorities about their impacts on human health and environmental sustainability. ${ }^{3,11}$ Thus, studies that contribute to a better understanding of agrochemicals and their effects on ecosystems and human health are timely.

Thus, the objective of this work was to investigate the history of the production and use of pesticides, their classifications, sources of exposure and their risks to human health.

\section{MATERIAL AND METHODS}

The research was carried out through review in specialized literature, conducted between May and June 2018, in which a search was conducted with online books and periodicals, by scientific articles selected in the databases of SciELO (Scientific Electronic Library Online) and CAPES (Coordination for the Improvement of Higher Education Personnel). The keywords used in the search were "pesticides history”, "structural classification”, “toxicological classification", "sources of exposure" and "risks to human health". 


\section{RESULTS}

\subsection{PESTICIDES HISTORY}

The use of chemicals in pest control and elimination dates back to Roman, Greek and Chinese times over 3000 years ago. There have been reports that these civilizations used sodium chloride to kill weeds and sulfur dust to control insects. ${ }^{6}$

In the nineteenth century, with the discovery of the copper acetoarsenite, popularly known as the "Paris Green", to combat the potato beetle, the first major landmark in the history of synthetic pesticides. ${ }^{6}$

During the nineteenth century until the mid-twentieth century, the chemicals developed were used for public health or for war purposes. Examples include dichlorodiphenyltrichloroethane (DDT), discovered in 1874, widely used by soldiers during Second World War, which pulverized the compound by the body to prevent and control diseases such as malaria and typhus. The properties as pesticide of this compound were only discovered sixty-five years later. ${ }^{6}$

In 1943, organophosphates, also known as "nerve gas", were used to combat enemy troops during Second World War. ${ }^{12}$ After the period of the world wars, strategies of growth of the companies of the chemical branch were created in search of new markets in which they could use the molecules developed until the moment. From this, the agrochemical industries, which already existed since the First World War, began to expand. ${ }^{6}$

In Brazil, the use of pesticides was disseminated during the years 1945 to 1985 , known as the period of modernization of national agriculture. It was also during this period that the installation of agrochemical industry in the country was carried out by the main manufacturers of these products worldwide. ${ }^{6}$

In the mid-1950s, with the growth of the world population and, consequently, the increase in demand for food, the development of increasingly efficient agricultural systems was boosted. ${ }^{13}$ Since then, the use of agrochemicals has been the main strategy to control and prevent pests during cultivation and after harvesting, improving productivity and quality of agricultural production. ${ }^{1,2}$ 


\subsection{PESTICIDES CLASSIFICATIONS}

Agrochemicals can be classified according to action targets, mode of action, chemical structure and toxicity. ${ }^{14}$ This classification makes it possible to know information about the chemical behavior of the substance used as a pesticide, such as persistence in the environment and its action on the target organism and on humans that may become contaminated.

\subsubsection{Action targets}

Due to the different biological targets, the agrochemicals market is segmented into different action targets, the main ones being: herbicides (control of weeds), fungicides (control of fungal diseases) and insecticides (control of insects). Of these, herbicides and fungicides have the highest volume of exports and imports in the world, with $45 \%$ and $14 \%$, respectively. ${ }^{11}$

\subsubsection{Action mode}

Pesticides can be classified as contact, ingestion or systemic according to the mode of action. Contact pesticides act on the surface of the food, directly affecting the target organism, while those of ingestion act after the biocide is ingested by the biological target. However, systemic pesticides penetrate the sap of the plant and travel through all vascular tissues, exerting a phytotoxic action in the case of herbicides or acting against insects when they feed on the sap. ${ }^{6}$

Systemic pesticides and part of the contact pesticides are absorbed by the plant's internal tissues and, if the appropriate dosage and shelf life are not respected or have not been degraded by the plant metabolism itself, they may remain in the food even if they are sanitized. ${ }^{14}$ 


\subsubsection{Chemical structure}

As for the chemical structure, the main classes of pesticides are organochlorines, organophosphates, pyrethroids and carbamates. ${ }^{6}$ In Figure 1, some characteristics about chemical behavior, persistence in the environment and action on organisms, and examples of chemical structures of each class are presented.

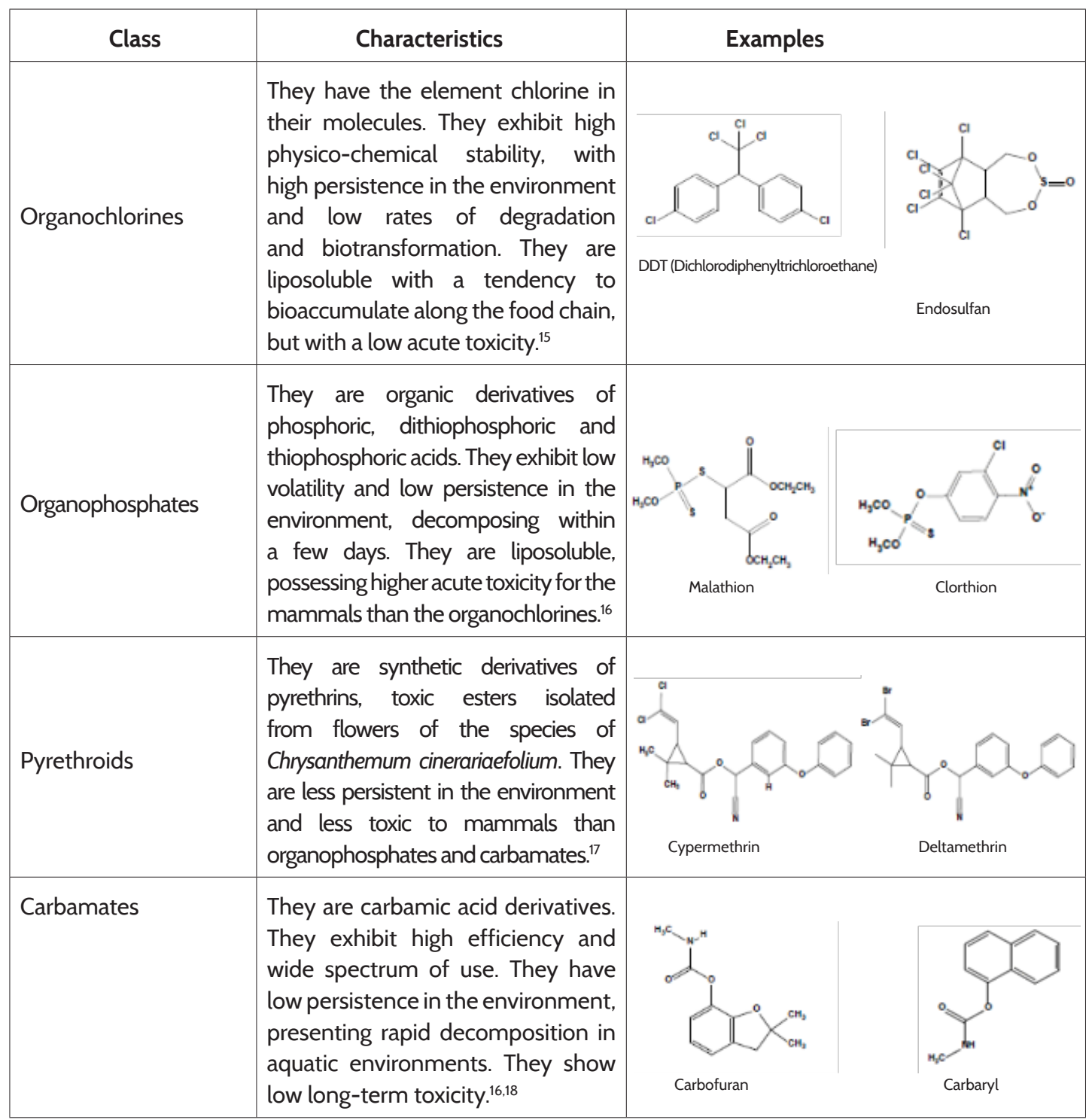

Figure 1 - Classification of chemical structure, behavior characteristics, persistence in the environment and action on organisms, and examples of chemical structures of each class of pesticide. 


\subsubsection{Toxicity}

A significant criterion for the classification of pesticides is their degree of toxicity. This classification is essential for the knowledge of the acute effects that pesticides can cause. ${ }^{19}$

The classification proposed by the World Health Organization ${ }^{19}$ considers three factors: the average lethal dose (LD50) of the formulated pesticide, the contact form of the pesticide (oral or dermal) and the type of formulation (solid or liquid). Referring to LD50, this consists of the amount of the toxic substance producing a $50 \%$ mortality of the test animals, under controlled conditions for a time of 24 hours, expressed in milligrams of pesticide per kilogram of animal weight $(\mathrm{mg} / \mathrm{Kg}) .{ }^{20}$

In Brazil, the toxicological classification is in charge of the Ministry of Health, which determines that all products must present on the labels a colored band indicative of its toxicological class. ${ }^{16}$ In Table 1 , it is possible to visualize the toxicological classes, the staining of the strip and the LD50 according to the type of formulation and the form of contact.

\begin{tabular}{lrrrr}
\hline & \multicolumn{4}{c}{ LD50 to rats (mg.kg-1 of body weight) } \\
\cline { 2 - 5 } Pesticide class & \multicolumn{1}{c}{ Way } & & & \\
& \multicolumn{1}{c}{ Oral } & \multicolumn{1}{c}{ Dermal } & & \\
\cline { 2 - 5 } & \multicolumn{1}{c}{ Solid } & \multicolumn{1}{c}{ Liquid } & \multicolumn{1}{c}{ Solid } & \multicolumn{1}{c}{ Liquid } \\
\hline Class I - Extremely toxic (red band) & $<5$ & $<20$ & $<10$ & $<40$ \\
Class II - Highly toxic (yellow band) & 5 a 50 & 20 a 200 & 10 a 100 & 40 a 400 \\
Class III - Moderately toxic (blue band) & 50 a 500 & 200 a 2000 & 100 a 1000 & 400 a 4000 \\
Class IV - Low toxic (green band) & $>500$ & $>2000$ & $>1000$ & $>4000$ \\
\hline
\end{tabular}

Table 1 - Toxicological classification of pesticides

Source: Larini (1999).7

Another existing classification, provided by the International Agency for Research on Cancer (IARC), is the carcinogenic potential of chemicals, agents and exposures to humans. This classification is based on evidence from epidemiological and laboratory studies on the carcinogenicity of substances ${ }^{21}$ (Figure 2). 


\begin{tabular}{|l|l|}
\hline Group & Characteristics \\
\hline Group 1 & Carcinogenic to humans \\
\hline Group 2A & Probably carcinogenic to humans \\
\hline Group 2B & Possibly carcinogenic to humans \\
\hline Group 3 & Not classifiable as carcinogenic in humans \\
\hline Group 4 & Probably not carcinogenic to humans \\
\hline
\end{tabular}

Figure 2 - Classification according to the carcinogenic potential of chemical substances, agents and exposures. Source: International Agency for Research on Cancer. ${ }^{21}$

It is necessary to observe that even the active ingredients being classified as medium or low toxic, prolonged exposure for months, years and even decades can trigger chronic effects such as the development of cancer, congenital malformations, endocrine and neurological disorders. ${ }^{4}$

\subsection{BRAZIL AND THE PESTICIDES}

Brazil is characterized as a country with a large rural area and a favorable climate for agricultural production. Due to this and the agricultural model, agrochemicals are extensively used in Brazilian crops. ${ }^{3}$

The Brazilian market for agrochemicals showed a significant growth of $10 \%$ per year between 1977 and 2006, so that Brazil was, from the mid-1970s to 2007, among the six largest consumers of agrochemicals in the world. ${ }^{11}$

Since 2008, Brazil has assumed the position of the largest consumer of pesticides in the world, a position formerly occupied by the United States, representing $19 \%$ of world use and moving more than US $\$ 7$ billion in agrochemicals. ${ }^{3,4,11}$

However, this data contradicts the relationship between productivity and consumption, considering that the main agricultural producer in the world is the United States, with $27 \%$, while Brazil ranks second, with $19 \%$ of the share of world food production. ${ }^{22}$

In Brazil, agricultural crops that most use agrochemicals are soy, corn and sugarcane, accounting for $82 \%$ of total agrochemical use in $2015 .{ }^{5}$ The Brazilian regions with the greatest intensity of these crops coincide with the highest concentrations of 
pesticide use: Mato Grosso (18.9\%), São Paulo (14.5\%), Paraná (14.3\%), Rio Grande do Sul (10.8\%), Goiás (8.8\%), Minas Gerais (9.0\%), Bahia (6.5\%), Mato Grosso do Sul (4.7\%) and Santa Catarina $(2.1 \%))^{23}$

Another characteristic point about the use of agrochemicals in Brazil is that several pesticides scientifically recognized as harmful to public health and the environment, banned in different countries, are still in circulation in Brazil. According to ANVISA, 22 of the 50 most widely used and allowed active ingredients in the country's crops are banned in the European Union, making Brazil the largest consumer of agrochemicals banned in other countries. ${ }^{11}$

The adoption of the Brazilian agricultural model, which uses pesticides on a large scale and indiscriminately, has been worrying public authorities about their impacts on human health and environmental sustainability. ${ }^{3,11}$

\subsection{HUMAN EXPOSURE TO PESTICIDES}

Exposure to pesticides can occur directly through occupational exposure, or indirectly, through environmental exposure and food. ${ }^{24}$

Agricultural work is one of the most dangerous occupations today, being the workers or residents of areas close to plantations exposed directly and indirectly to pesticides. ${ }^{4}$

The population in general, which does not work directly with agrochemicals or does not live in rural areas, is not exempt from the impacts of these compounds, having contact with pesticides through the environment and food. ${ }^{4}$

The main routes of human exposure to pesticides occur by residues in food, air, water, soil, flora and fauna. ${ }^{24}$ This is because once in the environment, pesticides can be distributed, degraded or accumulated in the environment compartments and in living beings. ${ }^{25}$

In Brazil, from 2002 to 2011, there was an increase in the average consumption of agrochemicals in relation to the planted area, from ${ }^{10.5}$ liters per hectare (L/ha) in 2002 to $12 \mathrm{~L} / \mathrm{ha}$ in 201111 increasing the risk of contamination of soil, water and food by pesticides, as well as exposure of humans to these compounds. 
Food analyzes have been demonstrating quantities of excessive agrochemical residues in plant foods, especially in fruits and vegetables. Data indicate that one-third of the food consumed daily by Brazilians presents contamination by pesticides above that allowed by legislation. ${ }^{26}$ In a study by Granella et al., ${ }^{27}$ it was observed contamination above legal values and by pesticides banned in Brazil in samples of conventional and organic milk. In addition, analyzes performed on breast milk showed the presence of organochlorine pesticide residues, indicating that exposure to pesticides begins early in childhood. ${ }^{28}$

\subsection{PESTICIDES AND RISISS TO HUMAN HEALTH}

The use of agrochemicals in Brazil has had serious consequences for the health of the population. These consequences are most often conditioned by occupational activity, by the toxicity of the active ingredients used as pesticides, by inadequate use or lack of personal protective equipment (PPE)..$^{10}$

The impacts on human health are divided into two forms: the acute form, which occurs through direct intoxication by the pesticide, be it at the time of application of this or the intake of a highly contaminated food, and the chronic form, due to long exposure. ${ }^{29}$

The World Health Organization (WHO) estimates that about 3\% of workers exposed to pesticides end up suffering some form of intoxication, making a total of approximately three million human poisonings per pesticide worldwide over a year. ${ }^{30}$

Studies have shown that the epidemiological profile of pesticide intoxications in Brazil occurs in the majority of cases in males, at a productive age, with a higher percentage of accidental intoxication, followed by intentional circumstances. ${ }^{31,32}$

In addition to acute effects, such as intoxication, prolonged human exposure to pesticides may result in neurological, reproductive, teratogenic and immunological disorders ${ }^{8-10}$

In a study by Fassa et al. ${ }^{33}$ showed that pesticides used in tobacco cultivation are significantly associated with neurobehavioral disturbances in tobacco growers. Some substances have properties that can affect the central nervous system, causing psychiatric disorders and leading to suicide. ${ }^{34}$ In addition, epidemiological studies have found a positive 
relationship between occupational exposure to pesticides and the risk of developing Parkinson's disease..$^{35,36}$

In studies conducted by Raafat, Abass and Salem ${ }^{37}$ and Malekirad et al., ${ }^{38}$ it has been shown that organophosphate pesticides may cause insulin resistance in farmers, who are more susceptible to developing diabetes mellitus.

Cancer is among one of the major diseases caused by chronic exposure to pesticides. Evidence suggests that exposure to low concentrations of pesticides may already increase the risk of developing prostate, pancreatic, liver, breast and rectal cancer, as well as leukemias and lymphomas. ${ }^{39-41}$

Studies have suggested that pesticides act by influencing the activity of the immune system, inducing the production of proinflammatory cytokines such as interleukin-6 (IL-6), interleukin-1 $\beta$ (IL-1 $\beta$ ) and tumor necrosis factor- $\alpha$ (TNF- $\alpha$ ), promoting the progression of the tumor through the activation of the inflammatory process. ${ }^{42,43}$

\section{CONCLUSION}

The use of pesticides, whether in wars, to combat diseases related to public health or agriculture, dates back many years. Pesticides have several classifications of action spectrum, mode of action, chemical structure and toxicological classification, which provide information on the degradation, accumulation and risk of each substance. Although agrochemicals have the role of eliminating harmful biological forms in agriculture, they can cause adverse health effects when used improperly, in accordance with the recommendations. Human exposure to pesticides can occur through direct or indirect contact, mainly by the presence of pesticide residues in food. The impacts on human health are divided into two forms: the acute form, which occurs through direct intoxication by the pesticide, and the chronic form, due to long exposure, which may result in neurological, reproductive, teratogenic and immunological disorders.

The results presented in this literature review contribute to a better understanding of agrochemicals and their effects on human health. 


\section{CONFLICT OF INTEREST}

The authors declare that there are no conflicts of interest.

\section{FUNDS}

This reserach was supported by Brazilian financial support from "Coordenação de Aperfeiçoamento de Pessoal de Nivel Superior (CAPES)", and "Conselho Nacional de Desenvolvimento Científico e Tecnológico (CNPq)".

\section{REFERENCES}

1. González-Rodríguez RM, Rial-Otero R, Cacho-Grande B, Simal-Gándara J. Occurrence of fungicide and insecticide residues in trade samples of leafy vegetables. Food Chem. 2008; 107(3):1342-7.

2. Brasil. Ministério do Meio Ambiente. Segurança Química. Agrotóxicos. Brasília; 2013. [cited 2018 May 16]. Available from: http://www.mma.gov.br/seguranca-quimica/ agrotoxicos

3. Bastos LHPB, Cardoso MHWM. Possiveis fontes de contaminação do alimento leite, por agrotóxicos, e estudos de monitoramento de seus resíduos: uma revisão nacional. Cad. Saúde Colet. 2011; 19(1):51-60.

4. Carneiro FF, Augusto LGS, Rigotto RM, Friedrich K, Búrigo AC. Dossiê ABRASCO: um alerta sobre os impactos dos agrotóxicos na saúde. 1. ed. Rio de Janeiro: EPSJV; São Paulo: Expressão Popular, 2015.

5. Pignati WA, Souza e Lima FAN, Correa MLM, Barbosa JR, Leão LHC, Pignatti MG. Distribuição espacial do uso de agrotóxicos no Brasil: uma ferramenta para a Vigilância em Saúde. Ciênc. Saúde Colet. 2017; 22(10):3281-93.

6. Barbosa LCAB. Os pesticidas, o homem e o meio ambiente. 1. ed. Viçosa: Editora UFV; 2004.

7. Larini L. Toxicologia. 3. ed. São Paulo: Editora Manole; 1999. 
8. Franco R, Li S, Rodriguez-Rocha H, Burns M, Panayiotidis MI. Molecular Mechanisms of Pesticide-Induced Neurotoxicity: Relevance to Parkinson's Disease. Chem.-Biol. Interact. 2010; 188(2):289-300.

9. Ma J, Li X. Alteration in the cytokine levels and histo $\neg$ pathological damage in common carp induced by glyphosate. Chemosphere 2015; 128(1):293 8.

10. Kim KH, Kabir E, Jahan SA. Exposure to pesticides and the associated human health effects. Sci Total Environ. 2017; 575(1):525-35.

11. Agência Nacional de Vigilância Sanitária. Seminário Mercado de Agrotóxico e Classificação. Brasilia, DF: Anvisa; 2012 [cited 2018 May 18]. Available from: http://portal. anvisa.gov.br/wps/content/anvisa+portal/anvisa/sala+de+imprensa/menu+-+noticias+anos/2012+noticias/seminario+volta+a+discutir+mercado+de+agrotoxicos+em+2012.

12. Silva MFO, Costa LM. A indústria de defensivos agrícolas. Química BNDES Setorial 35 , 2012 [cited 2018 May 16]. Available from: http://bit.do/bndes35

13. Sharma D, Nagpal A, Pakade YB, Katnoria JK. Analytical methods for estimation of organophosphorus pesticide residues in fruits and vegetables: a review. Talanta 2010; 82(4):1077-89.

14. Agência Nacional de Vigilância Sanitária. Programa de Análise de Resíduos de Agrotóxicos (PARA), dados da coleta e análise de 2001 a 2007. Brasília: Anvisa, 2008. [cited 2018 May 15]. Available from: www.anvisa.gov.br

15. Alves MIR, Antoniosi Filho NR, Oliveira LG, Furtado STF. Avaliação da contaminação por pesticidas organoclorados em recursos hídricos do Estado de Goiás. Rev. Bras. Recur. Hídricos 2010; 15(1):67-74.

16. Santos VMR, Donnici CL. Compostos organofosforados pentavalentes: histórico, métodos sintéticos de preparação e aplicações como inseticidas e agentes antitumorais. Quím Nova 2007; 30(1):159-70.

17. Santos MAT, Areas MA, Reyes FGR. Piretróides: uma visão geral. Alim. Nutri. 2007; 18(3):339-49.

18. Sanches SM, Silva CHTP, Campos SX, Vieira WM. Pesticidas e seus respectivos riscos associados à contaminação da água. Rev. Ecotox. Meio Ambient. 2003; 13(1):53-8.

19. World Health Organization. The WHO recommended classification of pesticides by hazard and guidelines to classification 1990-1991. 1991 [cited 2018 May 15]. Available from: http://whqlibdoc.who.int/hq/1990/WHO_PCS_90.1_REV.1.pdf 
20. Copplestone JF. The development of the WHO Recommended Classification of Pesticides by Hazard. Bull. World Health Organ. 1988; 66(5):545-51.

21. International Agency for Research on Cancer. IARC monographs on the evaluation of carcinogenic risks to humans. 1987 [cited 2018 May 10]. Available from: http://monographs.iarc.fr/

22. Food and Agriculture Organization. Statistics Division. Food and nutrition in numbers. 2014 [cited 2018 May 14]. Available from: http://apps.fao.org

23. Instituto Brasileiro de Geografia e Estatística. Censo Agropecuário 2006. 2006 [cited 2018 May 08]. Available from: http://www.ibge.gov.br/home/estatistica/economia/ agropecuaria/censoagro/brasil_2006/Brasil_censoagro2006.pdf

24. Anderson SE, Meade BJ. Potential health effects associated with dermal exposure to occupational chemicals. Environ. Health. Insights 2014; 8(1):51-62.

25. Pinheiro A, Moraes JCS, Silva MR. Pesticidas no perfil de solos em áreas de plantação de cebolas em Ituporanga, SC. Rev. Bras. Eng. Agric. Ambient. 2011; 15(5):533-8.

26. Agência Nacional de Vigilância Sanitária. Programa de Análise de Resíduos de Agrotóxicos (PARA), dados da coleta e análise de 2010. Brasília, DF: Anvisa; 2011 [cited 2018 May 6]. Available from: www.anvisa.gov.br

27. Granella V, Ventorini CG, Pigatto GM, Nornberg JL, Costabeber IH. Resíduos de agrotóxicos em leites pasteurizados orgânicos e convencionais. Semina: Ciências Agrárias 2013; 34(4):1731-40.

28. Pirsaheb M, Limoee M, Namdari F, Khamutian R. Organochlorine pesticides residue in breast milk: a systematic review. Med. J. Islam. Repub. Iran. 2015; 29(1):1-10.

29. Gangemi S, Gofita E, Costa C, Teodoro M, Briguglio G, Nikitovic D, et al. Occupational and environmental exposure to pesticides and cytokine pathways in chronic diseases (Review). Int J Mol Med. 2016; 38(4):1012-20.

30. WHO. The WHO Recomended Classification of Pesticides by Hazard and Guideline to Classification. 2009 [cited 2018 May 22]. Available from: http://www.who.int/ ipcs/publications/pesticides_hazard_2009.pdf

31. Rebelo FM, Caldas ED, Heliodoro VO, Rebelo RM. Intoxicação por agrotóxicos no Distrito Federal, Brasil, de 2004 a 2007- Análise da notificação ao Centro de Informação e Assistência Toxicológica. Ciênc. Saúde Colet. 2011; 16(8):3493-502.

32. Malaspina FG, Zinilise ML, Bueno PC. Perfil epidemiológico das intoxicações por agrotóxicos no Brasil, no período de 1995 a 2010. Cad Saúde Colet. 2011; 19(4):425-34. 
33. Fassa G, Faria NM, Meucci RD, Fiori NS, Miranda VI, Facchini LA. A. Green Tobacco Sickness Among Tobacco Farmers in Southern Brazil. Am J Ind Med. 2014; 57(6):223-300.

34. Riley P, Cotter J, Contiero M, Watts $M$. Herbicide Tolerance and GM crops: Why the World should be Ready to Round Up Glyphosate. GM Freeze and Greenpeace; 2011 [cited 2018 May 20]. Available from: http://www.greenpeace.org/international/en/ publications/reports/Herbicide-tolerance-and-GM-crops/

35. Moisan F, Spinosi J, Delabre L, Gourlet V, Mazurie JL, Bénatru I, et al. Association of Parkinson's disease and its subtypes with agricultural pesticide exposures in men: a case-control study in France. Environ Health Perspect. 2015; 123(11):1123-9.

36. James KA, Hall DA. Groundwater pesticide levels and the association with Parkinson disease. Int J Toxicol. 2015; 34(3):266-73.

37. Raafat N, Abass MA, Salem HM. Malathion exposure and insulin resistance among a group of farmers in Al Sharkia gover $\neg$ no rate. Clin Biochem. 2012; 45(18):1591 5.

38. Malekirad AA, Faghih M, Mirabdollahi M, Kiani M, Fathi A, Abdollahi M. Neurocognitive, mental health, and glucose disorders in farmers exposed to organophosphorus pesticides. Arh. Hig. Rada. Toksikol. 2013; 64(1):1 8.

39. Van Maele-Fabry G, Libotte V, Willems J, Lison D. Review and meta analysis of risk estimates for prostate cancer in pesticide manufacturing workers. Cancer Causes Control 2006; 17(4):353 73.

40. Antwi SO, Eckert EC, Sabague CV, Leof ER, Hawthorne KM, Bamlet WR, et al. Exposure to environmental chemicals and heavy metals, and risk of pancreatic cancer. Cancer Causes Control 2015; 26(11):1583 91.

41. Fenga C. Occupational exposure and risk of breast cancer. Biomed Rep. 2016; 4(3):282 92.

42. Costa C, Gangemi S, Giambó F, Rapisarda V, Caccamo D, Fenga C. Oxidative stress biomarkers and paraoxonase1 polymorphism frequency in farmers occupationally exposed to pesticides. Mol Med. 2015; 12(4):6353 7.

43. Medina Díaz IM, Ponce-Ruiz N, Ramírez-Chávez B, Rojas-García AE, Barrón-Vivanco BS, Elizondo G, et al. Downregulation of human para $\neg$ oxonase 1 (PON1) by organophosphate pesticides in HepG2 cells. Environ Toxicol. 2016; 32(2):490-500.

Recebido em: 06 de julho de 2018 Avaliado em: 28 de novembro de 2018 (AVALIADOR A) Avaliado em: 15 de fevereiro de 2019 (AVALIADOR B) Aceito em: 15 de fevereiro de 2019 
